\section{Medical journal in gun-ban challenge}

\section{Washington}

IN Maryland the health consequences of hand-gun ownership became a referendum issue and ended up testing the muchdebated publication policies of the New England Journal of Medicine. The referendum had its roots in a bill adopted by the Maryland legislature to restrict the availability of so-called Saturday-night specials, cheap hand-guns often used in assaults. The National Rifle Association supported a vigorous assault on the new law, obtaining enough signatures to force a state-wide vote.

On 8 November, the day of the vote, the influential Washington Post newspaper decided to break a New England Journal of Medicine embargo and give advance publicity to an article showing that hand-gun controls appear to reduce the frequency of urban violent crimes. The article, by John Henry Sloan et al., appearing in the $\mathbf{1 0}$ November issue, argues that the smaller number of homicides and aggravated assaults in Vancouver relative to neighbouring Seattle, Washington is related to Canada's strict gun-control laws.

Arnold Relman, editor-in-chief of the Journal, who earlier barred Reuters from receiving advance copies after the news agency broke an embargo declined to comment on the Washington Post's decision. But he said "our position on the embargo has never been absolute. On rare occasions when there is the perception by us or others that the information in an article is so important that it ought to be released immediately, we have lifted the embargo."

Whether the Washington Post article had a significant impact is unkown. But the following day voters threw out the challenge to the gun ban. It was the National Rifle Association's first defeat in a state referendum. Joseph Palca

\section{Refuges threaten endangered species} Washington

US National Wildlife Refuges are killing the creatures they are supposed to be saving, according to a report released two weeks ago by the Wilderness Society. The federal government has appropriated $\$ 51 \cdot 7$ million for the upkeep and preservation of these refuges, but the society claims that commercial development and agricultural runoff containing pesticides and heavy metals are ruining wildlife refuges. Kesterson National Waterfowl Refuge in California became a cause célèbre when toxins in surrounding waters killed birds that landed there. The society says that officials at Kesterson have to spend much of their energy trying to scare wildlife away.

Lisa L. Lyles

\title{
Global warming becomes an international political issue
}

\section{Hamburg}

THE discussion about global warming due to a 'greenhouse effect' could become one of the major political issues of the next century, according to delegates at the Climate and Development conference in Hamburg last week. The debate is being fuelled by the results of studies on the effects of temperature on resources such as water and energy, and on tourism, agriculture and other industries. If global temperature changes are to be controlled, concerted international action on an international level will be necessary, but political wrangling could obstruct a consensus.

Discussions at the conference centred around means of reducing emissions of greenhouse gases, but Mikhail Budyko of the Soviet state committee for hydrometeorology outlined the potential benefits of greenhouse gas emissions for agriculture in barren areas such as the tundra. His argument was received like "swearing in the church", said one delegate. But it is an argument that is sure to emerge again as politicians attempt to assess what action is needed to tackle climate change.

A plan for the development of government policies was formulated at the meeting. But more research is needed before governments will implement any policies; research not just into the scientific facts but into impacts on the economy and society of each nation.

One of the problems hindering such studies, said Martin Parry of the University of Birmingham, is the absence of a robust model with which to analyse the economic costs and benefits of adapting to climatic change. In a report for the Organisation for Economic Cooperation and Development (OECD), which will be published next month, he recommends that a methodology be formulated for member countries. At the beginning of next year, the OECD will begin a study of the greenhouse effect and its implications for future energy use and economic policies - and aims to formulate methods for costbenefit analysis and risk assessment.

Also embarking on a major study of the socio-economic impact of climate change is the inter-governmental panel set up by the World Meteorological Organisation and the United Nations Environment Programme. When the panel met last week for the first time it set a tight schedule for the study: the programmes of each of three working groups will be reviewed in about three months, with full reports expected in 18 months. The results of both studies will be presented at the second world climate conference of UNEP and the WMO in 1990. If an international law of the air is considered necessary, a preliminary draft of the law could be available by 1992 .

In the meantime, the conference timetable is filling up for researchers, politicians and environmentalists concerned with the greenhouse effect. One delegate said he knew of about 15 such conferences next year. The "travelling circus" of the greenhouse debate has begun, said another last week. If each one tries to better its predecessors, then delegates might be calling for a 100 per cent reduction in $\mathrm{CO}_{2}$ emissions before the year is out.

Christine McGourty

\section{US-Soviet Solar System collaboration}

\section{Washington}

Closer cooperation between the United States and the Soviet Union in the exploration of the Solar System is promised in an agreement signed in Washington last week by senior representatives from both sides. Some joint work, including exchange of data and the participation of scientists from one country in the missions of the other, is already under way, but the new agreement opens up the possibility of Soviet spacecraft carrying US instruments, and vice versa. Academician Valery Barsukov, head of the Soviet delegation, announced that all future Soviet missions to Mars, planned and expected, would now be open to international cooperation.

The agreement stems from a general programme of joint discussions set into motion with the signing in April 1987 of a US-Soviet treaty on cooperation in space science. The joint working group on Solar System exploration has met twice since then, and both sides say they have been pleased by the speed with which cooperative projects have moved. Data from US Viking missions to Mars are being used by the Soviets to select possible Mars landing sites, and the Soviet Phobos- 2 craft is being tracked by the US Deep Space Network as it journeys to Mars.

No specific plans have yet been made for missions in which the two countries will share spacecraft facilities or even build them together, but one possibility mentioned by Barsukov is a sample-return mission to Mars. Although cooperation in space missions between the two countries has a long history, the new agreement marks the first time that detailed technical specifications of spacecraft will be exchanged. Manned exploration of space has not been discussed so far, but there was general optimism that there would also eventually be cooperation in that area.

David Lindley 